\title{
Design, Construction and Evaluation of a Simple Pressurized Solvent Extraction System
}

\author{
J. S. S. Pinto*,\# and F. M. Lanças \\ Instituto de Química, Universidade de São Paulo, CP 494, 13566-590 São Carlos-SP, Brazil
}

\begin{abstract}
Este trabalho descreve a construção e teste de um sistema simples de extração pressurizada com solvente (PSE). Uma mistura de acetona:água (80:20), a $80^{\circ} \mathrm{C}$ e 103,5 bar, foi utilizada para extrair dois herbicidas (Diuron e Bromacil) de uma amostra de solo contaminado. Os herbicidas foram identificados e quantificados por cromatografia líquida de alta eficiência acoplada a detector por arranjo de diodos (HPLC-DAD). O sistema também foi utilizado para extrair óleo de soja $\left(70{ }^{\circ} \mathrm{C}\right.$ e 69 bar) empregando pentano como solvente. O óleo extraído foi pesado e caracterizado através da análise dos ésteres metílicos dos ácidos graxos (ácidos mirístico $(<0,3 \%)$, palmítico $(16,3 \%)$, esteárico $(2,8 \%)$, oléico $(24,5 \%)$, linoléico $(46,3 \%)$, linolênico $(9,6 \%)$, araquídico $(0,3 \%)$, gadolêico $(<0,3 \%)$ e behênico $(0,3 \%))$ por cromatografia gasosa de alta eficiência com detecção por ionização em chama (HRGC-FID). Os resultados do sistema PSE foram comparados com os determinados pelos procedimentos tradicionais, ou seja, extração soxhlet para o óleo de soja e extração sólido-líquido seguida da extração em fase sólida (SLE-SPE) para os herbicidas no solo. Com o sistema PSE determinou-se 21,25 $\pm 0,36 \%(\mathrm{~m} / \mathrm{m})$ de óleo na soja, já com soxhlet 21,55 $\pm 0,65 \%(\mathrm{~m} / \mathrm{m})$. Para a extração dos herbicidas Diuron e Bromacil, utilizando o sistema PSE, a eficiência (recuperação) foi de $88,7 \pm 4,5 \%$ e $106,6 \pm 8,1 \%$, respectivamente. Já com o sistema SLP-SPE obteve-se 96,8 $\pm 1,0 \%$ e 94,2 $\pm 3,9 \%$. Os limites de detecção (LOD) e de quantificação (LOQ) para Diuron foram $0,012 \mathrm{mg} \mathrm{Kg}^{-1}$ e $0,040 \mathrm{mg} \mathrm{Kg}^{-1}$, respectivamente. Para Bromacil os LOD e LOQ foram $0,025 \mathrm{mg} \mathrm{Kg}^{-1} \mathrm{e} 0,083 \mathrm{mg} \mathrm{Kg}^{-1}$. A linearidade utilizada para Diuron ficou na faixa de 0,01 a $1,50 \mathrm{mg} \mathrm{L}^{-1}$ e para Bromacil de 0,02 a $1,50 \mathrm{mg} \mathrm{L}^{-1}$. O sistema PSE, devido à alta pressão e temperatura, possibilita extrações com consumo de solvente reduzido, eficientes, rápida, e uma atmosfera inerte a qual preserva as amostras e os analitos da decomposição.
\end{abstract}

This work describes the construction and testing of a simple pressurized solvent extraction (PSE) system. A mixture of acetone:water (80:20), $80^{\circ} \mathrm{C}$ and 103.5 bar, was used to extract two herbicides (Diuron and Bromacil) from a sample of polluted soil, followed by identification and quantification by high-performance liquid chromatography coupled with diode array detector (HPLC-DAD). The system was also used to extract soybean oil $\left(70^{\circ} \mathrm{C}\right.$ and $\left.69 \mathrm{bar}\right)$ using pentane. The extracted oil was weighed and characterized through the fatty acid methyl ester analysis (myristic $(<0.3 \%)$, palmitic $(16.3 \%)$, stearic $(2.8 \%)$, oleic $(24.5 \%)$, linoleic $(46.3 \%)$, linolenic $(9.6 \%)$, araquidic $(0.3 \%)$, gadoleic $(<0.3 \%)$, and behenic $(0.3 \%)$ acids) using high-resolution gas chromatography with flame ionization detection (HRGC-FID). PSE results were compared with those obtained using classical procedures: Soxhlet extraction for the soybean oil and solid-liquid extraction followed by solid-phase extraction (SLE-SPE) for the herbicides. The results showed: $21.25 \pm 0.36 \%(\mathrm{~m} / \mathrm{m})$ of oil in the soybeans using the PSE system and $21.55 \pm 0.65 \%(\mathrm{~m} / \mathrm{m})$ using the soxhlet extraction system; extraction efficiency (recovery) of herbicides Diuron and Bromacil of $88.7 \pm 4.5 \%$ and $106.6 \pm 8.1 \%$, respectively, using the PSE system, and $96.8 \pm 1.0 \%$ and $94.2 \pm$ $3.9 \%$, respectively, with the SLP-SPE system; limit of detection (LOD) and limit of quantification (LOQ) for Diuron of $0.012 \mathrm{mg} \mathrm{kg}^{-1}$ and $0.040 \mathrm{mg} \mathrm{kg}^{-1}$, respectively; LOD and LOQ for Bromacil of $0.025 \mathrm{mg} \mathrm{kg}^{-1}$ and $0.083 \mathrm{mg} \mathrm{kg}^{-1}$, respectively. The linearity used ranged from 0.04 to $1.50 \mathrm{mg}$ $\mathrm{L}^{-1}$ for Diuron and from 0.08 to $1.50 \mathrm{mg} \mathrm{L}^{-1}$ for Bromacil. In conclusion, using the PSE system, due to high pressure and temperature, it is possible to make efficient, fast extractions with reduced solvent consumption in an inert atmosphere, which prevents sample and analyte decomposition.

Keywords: pressurized solvent extraction (PSE), accelerated solvent extraction (ASE), pesticides, green analytical chemistry (GAC), oils

*e-mail: jsspinto@esalq.usp.br

\#Present Address: Escola Superior de Agricultura Luiz de Queiroz-

ESALQ/USP, 13418-900 Piracicaba-SP, Brazil 


\section{Introduction}

In recent years there has been an increasing interest in the control of harmful substances in the environment. Traditional analytical procedures present as characteristics a high consumption of solvent, large analysis time, intensive analyst work, and multi-stages processing. Modern analytical techniques for sample preparation on the other hand minimize the costs and maximize the quality of the analytical results in a shorter time. ${ }^{1-3}$

The actual tendency in sample preparation techniques includes to the use of solid phase extraction (SPE), ${ }^{4-6}$ supercritical fluid extraction (SFE), ${ }^{7,8}$ accelerated solvent extraction (ASE), ${ }^{9,10}$ microwave assisted extraction (MAE), ${ }^{11-13}$ and solid phase micro extraction (SPME). ${ }^{14-16}$ ASE (accelerated solvent extraction), or PSE (pressurized solvent extraction, a more generic term), is one of the newest extraction techniques. The results indicate to be a good alternative for the preparation of several samples, as Supercritical Fluid Extraction (SFE), it also subject of the high initial cost of the commercially available equipment. ${ }^{17}$ The fundamental difference between the extractions using PSE and SFE is the physical state of the extractor fluid: PSE uses fluid in the liquid state and SFE uses fluid in the supercritical state.

PSE uses small amount of organic solvents under high pressure (69-140 bar), to maintain solvent in a liquid phase, and temperature $\left(50-300{ }^{\circ} \mathrm{C}\right)$ above its boiling point to quickly extract analytes of solid and semi-solid samples. In this way a considerable increase in the solubility of the analytes, of interest and a maximization of the rates of mass transfer due to decrease of the viscosity and superficial tension of the solvents, doing that is reached areas no available by the conventional processes is observed. ${ }^{18}$

In the present work, a "home-made" PSE system was developed and used for extraction of oil from soybeans samples as well as the extraction of herbicides from a polluted soil sample. The data obtained with PSE, for soybeans samples, were compared to those obtained using the official AOAC (soxhlet) extraction method, and qualitative analysis of fatty acid based on the capillary gas chromatography of fatty acid methyl esters (FAMEs). ${ }^{19}$ For herbicides the efficiency of the process was verified by the recovery and compared with data obtained by using a conventional method, solid-liquid extraction followed by solid phase extraction (SLE-SPE) and analyzed by HPLC-DAD.

\section{Experimental}

\section{Solvents and materials}

Hexane, acetone and pentane degree Pro Analysis was supplied by Merck (Rio de Janeiro, RJ, Brazil); methanol and dichloromethane degree HPLC by Mallinckrodt Baker Inc (Paris, Kentucky, USA); Bromacil and Diuron herbicides (99.3\%) were supplied by DuPont (Paulínia, SP, Brazil), mixture $61 \mathrm{C}$ of fatty acid methyl esters supplied by PolyScience (Niles, IL, USA). The $\mathrm{C}_{18}(500 \mathrm{mg}$ ) cartridges were supplied by Varian (Harbor City, CA, USA).

\section{Construction of the PSE system}

The developed system, as illustrated in Figure 1, includes a pneumatic pressurization pump with capacity of approximately $350 \mathrm{~mL}$ of solvent, constituted by a stainless steel 304 pressurization vessel and a standard nitrogen cylinder; extraction cells of several sizes are made of stainless steel; an oven; two 3-way valve for solvent flow and gas purge; a 2-way valve, located after the extraction cell, to control the exit flow of the extract for the sample collector. The pressurization vessel was built in stainlesssteel 304 with an union made with electric welds and it is constituted with a stainless-steel tube with closed cap for screws made in stainless-steel, too hinder with "O" Ring of Teflon, it possesses a cap, through where the solvent is placed. In this cap there is a " $\mathrm{T}$ " shape connection through where the inert gas (nitrogen) enters for pressurization, it is an exit for the fluid already pressurized for the extraction cell and it is an exit of the purge gas the extraction cell.

\section{Samples}

\section{Soybeans samples}

Initially the soybeans were ground and sieve (23 mesh), being after dried in an oven at $105^{\circ} \mathrm{C}$ for $6 \mathrm{~h}$. The soybean sample was bought at the local market.

\section{Soil samples}

The soil samples were collected at the campus of the University of São Paulo, dried at $80^{\circ} \mathrm{C}$ for $24 \mathrm{~h}$, and sieved (23 mesh).

\section{Soybeans oil extraction}

\section{Soxhlet extraction}

Soybean samples $(8 \mathrm{~g})$, in triplicate, previously dried and grind, were submitted to the soxhlet extraction with $250 \mathrm{~mL}$ hexane, for $6 \mathrm{~h}$ in the solvent boiling 


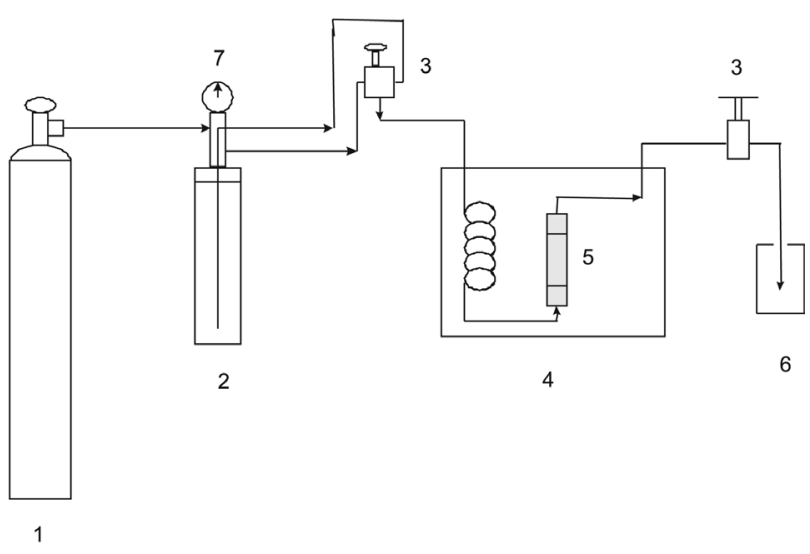

Figure 1. Schematic diagram of the pressurized solvent extraction (PSE) system. 1: Nitrogen tank; 2: Pressure vessel; 3: Valves; 4: Oven; 5: Extraction cell with filters; 6: Collector flask, 7: Manometer.

temperature. After the solvent was evaporated in rotary evaporator the remaining solvent still present in the oil was eliminated under a gentle and controlled nitrogen flow, at $25{ }^{\circ} \mathrm{C}$. The amount of oil obtained was determined by a weighing.

\section{PSE extraction}

The pressurization vessel was filled with pentane, and maintained at 69 bar. Samples ( $8 \mathrm{~g}$ of soybean) were weighed and placed in the stainless-steel extraction cell $(30 \mathrm{~cm}, 0.8 \mathrm{~cm}$ i.d.) and transferred to the oven previously heated to $70{ }^{\circ} \mathrm{C}$. Initially the cell was filled out with pentane and left to stand for $5 \mathrm{~min}$ to reach the working temperature. The extraction was started in the static mode, for $10 \mathrm{~min}$ with the of 2-way valve closed, followed by a dynamic extraction, with both valves open, for 10 minutes, at a flow of approximately $2 \mathrm{~mL} \mathrm{~min}^{-1}$. At the end of the extraction period the 3-way valve is changed for the purge position, to drain all solvent from the extraction cell. The solvent was evaporated in a rotary evaporator, after which the solvent that remained in the oil was eliminated under controlled nitrogen. The amount of oil was determined gravimetrically.

\section{Extraction of herbicides from soil}

\section{PSE extraction}

The pressurization vessel was filled with an acetone: water (80:20) mixture, and maintained under pressure at $103.5 \mathrm{bar}(15 \mathrm{~g})$, in triplicate, of polluted soil samples fortified with a mixture of Herbicides $\left(0.10 \mathrm{mg} \mathrm{kg}^{-1}\right)$ were loaded into the stainless-steel extraction cell $(30 \mathrm{~cm} \times$ $0.8 \mathrm{~cm}$ ) and transferred to the oven previously estabilized at $80{ }^{\circ} \mathrm{C}$. The extraction cell was filled out with the acetone:water (80:20) mixture and preheated for $5 \mathrm{~min}$, followed by $10 \mathrm{~min}$ of static extraction, and further $10 \mathrm{~min}$ of dynamic extraction at a flow rate of approximately $2 \mathrm{~mL}$ $\mathrm{min}^{-1}$. After finishing the extraction the system is purged to elimine all solvent remaning in the cell.

\section{SLP-SPE extraction}

$20 \mathrm{~g}$ of soil, in triplicate, previously dried and sieved, was treated with $2.0 \mathrm{~mL}$ of acetonitrile solution containing $1 \mathrm{mg} \mathrm{L}^{-1}$ of each herbicide. The sample was then homogenized in a mixer for $10 \mathrm{~min}$, and subsequently stored at room temperature in the darkness for $2 \mathrm{~h}$, prior to solid-liquid extraction (SLE) with $120 \mathrm{~mL}$ of the acetone:water (80:20) mixture using magnetic stirring for $30 \mathrm{~min}$. After stirring, the liquid fraction (acetone:water) was separated from the solid fraction and concentrated by a controlled nitrogen stream until approximately $25 \mathrm{~mL}$ of water remained in the flask.

For SPE a SUPELCO VISIPREP 24 DL $^{\mathrm{TM}}$ (Bellefonte, PA, USA) system was used. The cartridges containing $500 \mathrm{mg}$ of octadecilsilane $\left(\mathrm{C}_{18}\right)$ were conditioned with $5 \mathrm{~mL}$ of acetonitrile and $5 \mathrm{~mL}$ of water. The samples were passed trough the $\mathrm{C}_{18}$ cartridges under an adjusted vacuum at a flow rate of about $20 \mathrm{~mL} \mathrm{~min}^{-1}$. The cartridge was not allowed to dry completely during the extraction process. The pesticides were collected in $30 \mathrm{~mL}$ of acetonitrile:methanol mixture (50:50) being then transferred to a concentration tube and the solution was concentrated to $1.0 \mathrm{~mL}$.

\section{Fatty acid methyl esters (FAME) analysis by HRGC-FID}

$35 \mathrm{mg}$ of soy oil sample, in triplicate, was weighed into a $20 \mathrm{~mL}$ screw-cap tube to which $0.5 \mathrm{~mL}$ methanolic solution of $0.5 \mathrm{~mol} \mathrm{~L}^{-1}$ sodium hydroxide was added. The content of the capped tube was heated in a water bath (temperature $90{ }^{\circ} \mathrm{C}$ ) for $10 \mathrm{~min}$, after which the tube was removed from the bath and cooled in an ice bath. Then $1.5 \mathrm{~mL}$ of esterification solution (ammonium chloride ( $2 \mathrm{~g})$, methanol $(60 \mathrm{~mL})$, sulfuric acid $(3 \mathrm{~mL}))$ were added and the contents of the tube heated with the aid of a water bath (temperature $90{ }^{\circ} \mathrm{C}$ ) for $10 \mathrm{~min}$ cooled in an ice bath and $5 \mathrm{~mL}$ of hexane and $10 \mathrm{~mL}$ of water were added. A sample is taken from the clear upper layer (usually $1 \mu \mathrm{L}$ ) for GC analysis of FAMEs.

The gas chromatograph (GC) used was a Shimadzu GC-17 A equipped with an FID detector. All analyses were performed on a $30 \mathrm{~m} \times 0.25 \mathrm{~mm}$ i.d. LM 100 fused silica capillary column (LM, São Carlos, Brazil) coated with $0.35 \mu \mathrm{m}$ Superox (polyethylene glycol). Samples of $1 \mu \mathrm{L}$ were injected in the split mode (1:30). The temperature at the split injector was set to $250{ }^{\circ} \mathrm{C}$ and for FID detector $300{ }^{\circ} \mathrm{C}$. The column was held at $190{ }^{\circ} \mathrm{C}$ for $30 \mathrm{~min}$. The carrier gas was hydrogen (Aga, São Carlos, Brazil) at $70 \mathrm{kPa}$ head pressure. 
Table 1. Comparison of characteristics of soxhlet and PSE for soy oil extraction

\begin{tabular}{|c|c|c|c|c|c|}
\hline Method & Solvent & Solvent Volume / mL & Extraction time / min & $\%$ Oil $(\mathrm{m} / \mathrm{m})$ & Standard Deviation Estimate $(n=3)$ \\
\hline Soxhlet & Hexane & 250 & 360 & 21.55 & 0.65 \\
\hline PSE & Pentane & 20 & 20 & 21.25 & 0.36 \\
\hline
\end{tabular}

\section{Herbicides analysis by HPLC-UV-DAD}

Chromatographic analyses of selected herbicides, including Bromacil and Diuron extracted from soil samples were performed on a Shimadzu LC 10 AD Liquid Chromatography (Shimadzu, Japan), equipped with a binary solvent delivery system, an injection valve with a $20 \mu \mathrm{L}$ loop and a SPD-M10A diode array detector. The separation was carried out using a Supelcosil (Supelco, Bellefonte, PA, USA) $\mathrm{C}_{8}(25 \mathrm{~cm} \times 0.46 \mathrm{~cm}$ I.D., $5 \mu \mathrm{m}$ particle size) column. The herbicides were separated using acetonitrile:water (50:50; v:v), isocratic mode with a flow rate of $1.0 \mathrm{~mL} \mathrm{~min}{ }^{-1}$. The wavelength was $254 \mathrm{~nm}$. All solvents were degassed with helium. The columns were kept at $35^{\circ} \mathrm{C}$.

\section{Results and Discussion}

The PSE system developed and described in this work is easy to be used, showing possibilities of using several extraction cells having different sizes and shapes. With the exit valves closed it is possible to work in the static extraction, in which case the solvent fills the extraction cell and remain in it for the selected extraction time. This can be followed by opening the valve and a dynamic extraction mode process starts with fresh solvent being flushed through the cell during the new extraction time.

The cost of this system is very low when compared to most commercially available equipment, being of easy construction and maintenance.

One of the characteristics of the Soxhlet extraction is that the sample and the analytes of interest are submitted to non ideal conservation conditions, being usually exposed to the atmospheric air and high temperatures for a long period of time. Therefore in pressurized solvent extraction (PSE) systems samples are submitted to high pressures and high temperature for much short periods of time in an inert atmosphere that preserves the sample and the analytes from decomposition.

In our system the soy samples had their oil content (Table 1) easily extracted. Comparison made using PSE and soxhlet extraction showed equivalent results with reduction in solvent consumption $(20 \mathrm{~mL})$, instead of $250 \mathrm{~mL}$ as well as in analysis time, which now takes 20 min to carry out the extraction using PSE in comparison to $6 \mathrm{~h}$ required for the soxhlet.
The FAMEs analysis (Figures 2 and 3) showed that the extraction process (PSE and soxhlet) produces equivalent chromatographic profiles.
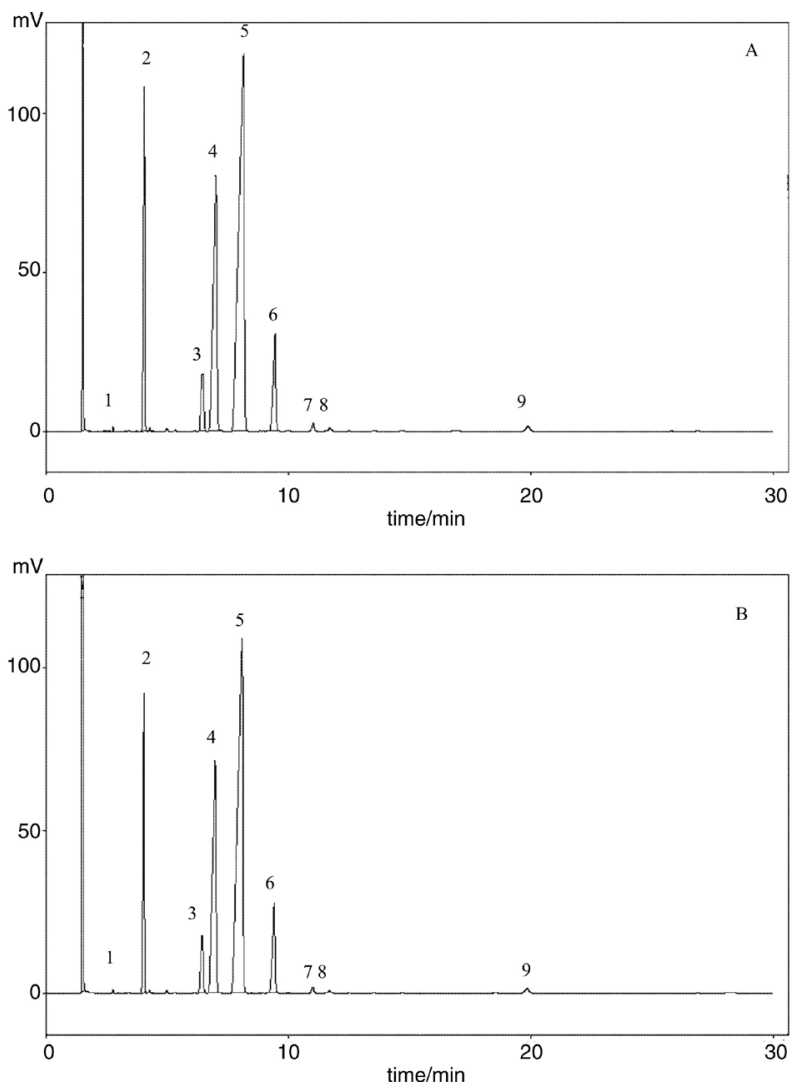

Figure 2. HRGC-FID chromatogram of fatty acid methyl esters (FAMEs) analysis of soy oil extracted by PSE system (A) and soxhlet (B). Peak assignment: 1-Myristic acid $(<0.3 \%)$; 2-Palmitic acid $(16.3 \%)$; 3-Stearic acid $(2.8 \%)$; 4-Oleic acid $(24.5 \%) ; 5$-Linoleic acid $(46.3 \%)$; 6-Linolenic acid $(9.6 \%)$; 7-Araquidic acid $(0.3 \%) ; 8$-Gadoleic acid $(<0.3 \%)$; 9-Behenic acid $(0.3 \%)$.

Table 2 and Table 3 show the analytical results obtained in the analysis of two herbicides (Diuron and Bromacil) from a sample of polluted soil.

The results obtained with herbicides recovery and validation (Table 2, Table 3 and Figure 3) using PSE system demonstrated the adequacy of the procedure for the extraction of Diuron and Bromacil. The recovery results were in the range $88-106 \%$. In this case just a fraction of time (20 $\mathrm{min}$ ) of the one used with the traditional method, SLE-SPE was required, to execute the analysis with very similar results. 


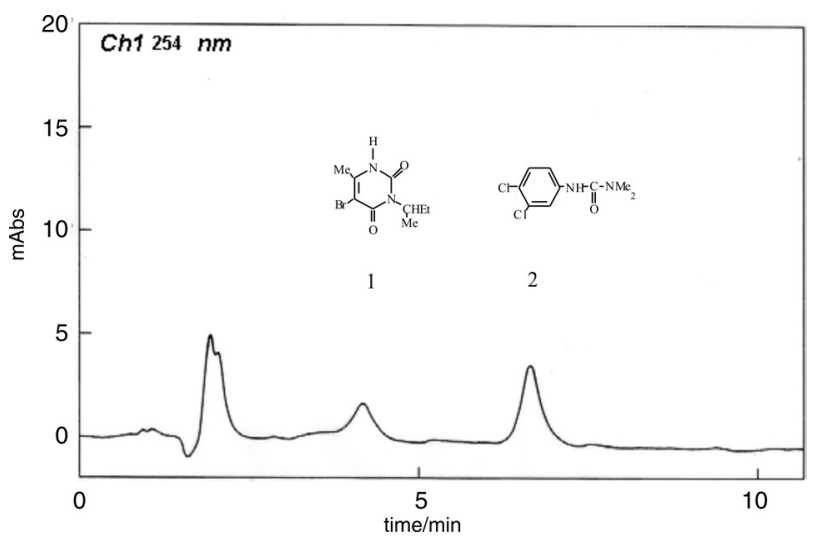

Figure 3. HPLC-DAD chromatogram of herbicides extracted from polluted soil $\left(0.10 \mathrm{mg} \mathrm{Kg}^{-1}\right)$ using PSE system. Peaks: 1-Bromacil; 2-Diuron.

Table 2. Recovery extraction of herbicides in soil

\begin{tabular}{lccccc}
\hline & $\begin{array}{c}\text { Spiked } \\
\text { level / } \\
\left(\mathrm{mg} \mathrm{Kg}^{-1}\right)\end{array}$ & \multicolumn{2}{c}{ \% Recovery } & \multicolumn{2}{c}{$\begin{array}{c}\text { Standard deviaton } \\
\text { estimate }\end{array}(\mathrm{n}=3)$} \\
SLE-SPE & 0.10 & 96.80 & 94.20 & 1.0 & 3.9 \\
PSE & 0.10 & 88.70 & 106.60 & 4.5 & 8.1 \\
\hline
\end{tabular}

Table 3. Analytical results

\begin{tabular}{lcccc}
\hline Compounds & $\begin{array}{c}\text { Retention } \\
\text { time / min }\end{array}$ & $\begin{array}{c}\text { LOD / } \\
\left(\mathrm{mg} \mathrm{L}^{-1}\right)\end{array}$ & $\begin{array}{c}\text { LOQ / } \\
\left(\mathrm{mg} \mathrm{L}^{-1}\right)\end{array}$ & $\begin{array}{c}\text { Linear range / } \\
\left(\mathrm{mg} \mathrm{L}^{-1}\right)\end{array}$ \\
\hline Bromacil & 4.8 & 0.025 & 0.083 & $0.08-1.50$ \\
Diuron & 6.7 & 0.012 & 0.040 & $0.04-1.50$ \\
\hline
\end{tabular}

\section{Conclusions}

The extraction results for soy oil and herbicides demonstrate the viability of the system; the same could be used with a great variation of solvents or mixtures of solvents that are more appropriate to a matrix of interest and multiple extraction cells in agreement with the sample volume to be used.

The built system showed to be appropriate to the proposed development of modern alternative instrumentation to substitute traditional extraction methods. The PSE system uses less solvent, spends less time, and is inexpensive, features that make it a green analytical chemistry (GAC) method that provides both environmental and economic benefits.

\section{Acknowledgments}

The authors thank the Conselho Nacional de Desenvolvimento Científico e Tecnológico (CNPq) and Fundação de Amparo à Pesquisa do Estado de São Paulo (FAPESP) for financial support.

\section{References}

1. Giray, E. S.; Kirici, S.; Kaya, D. A.; Turk, M.; Sonmez, O.; Inan, M. Talanta 2008, 74, 930.

2. Lee, M. H.; Lin, C. C.; Food Chem. 2008, 105, 223.

3. Wang, L. J.; Weller, C. L.; Trends Food Sci. Technol. 2006, 17, 300.

4. Gheorghe, A.; van Nuijs, A.; Pecceu, B.; Bervoets, L.; Jorens, P. G.; Blust, R.; Neels, H.; Covaci, A.; Anal. Bioanal. Chem. 2008, 391, 1309.

5. Jira, W.; Ziegenhals, K.; Speer, K.; Food Add. Contam. 2008, 25, 704 .

6. Kasprzyk-Horden, B.; Dinsdale, R. M.; Guwy, A. J.; Anal. Bioanal. Chem. 2008, 391, 1293.

7. Li, H.; Li, S.; Zhang, Y.; Duan, H.; J. Liq. Chromatogr. Relat. Technol. 2008, 31, 1422.

8. Freitas, L. d. S.; De Oliveira, J. V.; Dariva, C.; Jacques, R. A.; Caramao, E. B.; J. Agric. Food Chem. 2008, 56, 2558.

9. Beck, J.; Totsche, K. U.; Kogel-Knabner, I.; Chemosphere 2008, $71,954$.

10. Chen, J.; Loo, B.; Ray, C.; J. Agric. Food Chem. 2008, 56, 1829.

11. Itoh, N.; Numata, M.; Aoyagi, Y.; Yarita, T.; Anal. Chim. Acta 2008, 612, 44.

12. Wozniakiewicz, M.; Wietecha-Posluszny, R.; Garbacik, A.; Koscielniak, P.; J. Chromatogr., A 2008, 1190, 52.

13. Wang, X. P.; Jin, H. Y.; Ding, L.; Zhang, H. Q.; Qu, C. L.; Yu, A. M.; Talanta 2008, 75, 556.

14. Arthur, C. L.; Pawliszyn, J.; Anal. Chem. 1990, 62, 2145.

15. Aguinaga, N.; Campillo, N.; Vinas, P.; Hernandes-Cordoba, M.; Anal. Bioanal. Chem. 2008, 391, 1419.

16. Brown, S.; Rickrode, M.; Caldwell, T.; Fuel 2008, 87, 2334.

17. Levy, J. M.; Am. Lab. 1998, 30, 38F.

18. Richter, B. E.; Jones, B. A.; Ezzel, J. L.; Porter, N. L.; Anal. Chem. 1996, 68, 1033.

19. Antoniosi Filho, N.R.; PhD Thesis, Universidade de São Paulo, Brazil, 1995.

Received: September 8, 2008 Web Release Date: April 17, 2009

FAPESP helped in meeting the publication costs of this article. 